\title{
Samopodoba vodij v upravnih enotah
}

UDK: 35-057.17

Jernej Buzeti

Univerza v Ljubljani, Fakulteta za upravo

jernej.buzeti@fu.uni-li.si

Janez Stare

Univerza v Ljubliani, Fakulteta za upravo

janez.stare@fu.uni-li.si

\section{IZVLEČEK}

$\checkmark$ procesu vodenja lahko predvsem pozitivna samopodoba vodje vpliva na kakovosten medosebni odnos $z$ vodenimi oziroma na vedenje vodje in tudi vodenih. Rezultati izvedene raziskave samopodobe vodij $v$ upravnih enotah kažejo, da sta izmed proučevanih področij samopodobe najnižje izraženi predvsem socialna in telesna samopodoba, najvišje pa je izražena splošna samopodoba. Ker je za vodje pomembno, da imajo dobro razvite predvsem socialne spretnosti oziroma spretnosti za delo z ljudmi, je rezultat raziskave o socialni samopodobi vodij $v$ državni upravi (upravnih enotah) pomemben kazalnik podob vodii o njihovih predstavah na socialnem področju. Prispevek se osredotoča na samopodobo vodij upravnih enot in predstavlia rezultate opravljene raziskave s tega področja.

Ključne besede: vodja, socialna samopodoba, telesna samopodoba, samospoštovanje, upravna enota

JEL:ZOO

\section{Uvod}

Pomenu vodenja ljudi in primernosti vodij se $v$ slovenski državni upravi namenja vse več pozornosti tako na področju raziskovanja kot tudi pri praktičnem izvajanju. Ključni dejavnik vodenja je vodja, sai predstavlja osrednjo, središčno točko $v$ odnosu do vodenih. Uspešno vodenje ljudi zahteva od vodij, da imajo ustrezne kompetence, ki pomembno vplivajo

Buzeti, J. \& Stare, J. (2010). Samopodoba v upravnih enotah. 


\section{Samopodoba vodij $v$ upravnih enotah}

na to, da bodo doseženi zastavljeni cilji. Raziskave potriujejo, da osebnost vodje vpliva na uspešnost vodenja - in vodja si na podlagi svoje osebnosti izoblikuje tudi določeno predstavo o samem sebi. Torej predstavo o tem kaj si misli o sebi, svojih sposobnostih, lastnostih, o svojem telesu, možnostih $v$ življenju, uspehih in neuspehih. $V$ strokovni literaturi se za opis takšnih značilnosti uporablja izraz "samopodoba". V procesu vodenja ni vseeno, kakšen je vodja kot osebnost oziroma kakšna je njegova samopodoba, saj lahko določena predstava vodje o samem sebi vpliva na njegovo vedenje, ki se lahko prenese tudi na vodene oziroma njihovo vedenje.

\section{Vodenje in vodja}

$\checkmark$ literaturi zasledimo, da obstajajo različne' definicije vodenja, ki vodenje opredeljujejo $\mathrm{z}$ različnih ${ }^{2}$ vidikov. $V$ prispevku se vodenje razume kot vplivanje vodje na vodene $z$ namenom, da si vodeni želijo (hočejo) opraviti nalogo, za katero so se dogovorili z vodjem. Podobno menita tudi Hellriegel in Slocum (1996, str. 445), saj razumeta vodenje kot vplivanje na zaposlene, da ti delujejo $v$ smeri doseganja ciljev. Brajša (1983, str. 187) pa opredeliuje vodenje kot zapleten medosebni proces, saj gre pri vodenju za delo z ljudmi, ki so zapletena in zahtevna bitja.

Northouse (2007, str. 3) pojasnjuje, da je vodenje proces ${ }^{3}, v$ katerem poteka niz aktivnosti, in kot menijo Hočevar (2003, str. 130-131) in drugi »v takšnem procesu enakovredno sodelujejo vodja, vodeni in okoliščine«. Vodeni lahko v organizaciji oziroma socialni situaciji s svojim vedenjem silijo vodjo, da izbere ustrezen stil vodenja - toda vodja bo stil vodenja prilagodil tudi na okoliščine oziroma situacijo, $v$ kateri izvaja aktivnosti, in to s ciljem uspešno realizirati dogovorjeno oziroma zadano nalogo. Pri vodenju gre torej za proces, ki ga oblikujejo razmerja oziroma interakcije med vodjo, vodenimi in okoliščinami. Ključni dejavnik vodenja pa je vodja, $\mathrm{ki}$ »z zgledom in nasveti vodi sodelavce, da bi dosegel zastavljen organizacijski cilj" (Stare \& Seljak, 2006, str. 89). Gibb (v: Nastran Ule, 1994, str. 237) opredeljuje, da je vodja:

1 Nekatere so predstavili Bass, Antonakis, Yukl, Avolio, Bennis, Gardner, Kotter, Kovač, Mayer, itd.

2 Vodenje se lahko obravnava z antropološkega, psihološkega, sociološkega, tehnološkega, ekonomskega, organizacijskega, kulturološkega in drugih vidikov.

3 Podobno menijo tudi Bass (1990), Mayer (2004), Možina (1994), itd. 
- dominantna osebo z močjo in vplivom, s katerim deluje na obnašanje in aktivnosti drugih;

- "centralna oseba" za člane skupine, ego-ideal skupine;

- oseba, ki ima največji vpliv na druge in katerega vpliv skupina prostovoljno sprejema.

Vodja opravlja pomembne naloge $v$ procesu vodenja in ima $v$ organizaciji oziroma skupini osrednjo vlogo. Niegova vloga je pomembna, saj on ne samo vpliva na ljudi, da dosežejo dogovorjene cilje, njegova vloga je tudi $v$ tem, da je vzgled ljudem (tudi na področju morale oziroma etičnih standardov). Temu pritriuje tudi Branden (2000, str. 61), ki pravi, da "premalo vodilnih razume in ceni stopnjo, do katere so vzor drugim. Ne prepoznajo, kako podrobno ljudje okrog njih včasih nezavedno opazujejo in prevzemajo niihove drobne gibe in kako se njihov vpliv odraža $v$ celotni organizaciji pogosto vidno $v$ povratni reakciji $\vee$ vedenju vodenih. To vedenje je pomembno in izkustveno ugotavljamo, da mora vodja takšno vedenje zaznavati in izboljševati. Na vedenje oziroma na uspešnost vodenja lahko vpliva s svojimi sposobnosti, znanjem in lastnostmi. ${ }^{4}$ Toda Stare (2005, str. 86) meni, da je zmožnosti, ki naj bi jih imel posamezni vodja za uspešno vodenje, težko opredeliti in to tudi zaradi vpliva vodenih in posamezne situacije.

Yukl (2002, str. 195) meni, da so med spretnostmi predvsem spretnosti za delo z ljudmi ${ }^{5}$ bistvene za vplivanje na ljudi. Takšne spretnosti so znanja in sposobnosti za delo v skupini oziroma sposobnosti za vodenje določene skupine. Gre za spretnosti, ${ }^{6} \mathrm{ki}$ jih ima oziroma bi jih moral imeti vodja za delo z ljudmi, saj mu pomagajo k bolj učinkovitemu delu s podrejenimi oziroma vodenimi in to z namenom, da se dosežejo organizacijski cilji. Vodja, ki ima zelo dobro razvite takšne spretnosti oziroma sposobnosti, se zaveda svojega razpoloženja, domnev in prepričanj drugih posameznikov (vodenih) in skupin. Ustvarja tudi pozitivno klimo oziroma vzdušje zaupanja, v katerem se zaposleni (vodeni)

4 Znanje, sposobnosti in lastnosti (osebnostne, socialne) se lahko razume tudi kot človeške zmožnosti.

5 Angl. "human skill"

6 Bass (1990, str. 195) jih poimenuje tudi kot "socialne, družbene spretnosti" in meni, da s tem mislimo na sposobnosti, ki omogočajo razumevanje občutkov, razpoloženja in motivov vodenih ter sposobnosti dobre komunikacije in prepričevanja. 


\section{Samopodoba vodij $v$ upravnih enotah}

počutijo udobno in varno. Takšne spretnosti so pomembne, saj gre tudi za motiviranje in razumevanje vodenih (po Katz, 1955, str. 34-35). Bass (1990, str. 110) pojasnjuje, da so raziskave pokazale, da so takšne spretnosti zelo pomembne in vplivajo na uspešnost in napredek vodje oziroma na uspešnost vodenja. To potriuje tudi z raziskavo, ki jo je izvedel Boyatzis (1982), sai je pokazala, da se na podlagi spretnosti dela z ljudmi ločijo uspešni vodje od neuspešnih. Nastran Ule (1994, str. 237) pa pojasnjuje, da so spretnosti vodje povezane z nalogami, ki jih mora opraviti; pomembne naloge vodje so predvsem psihološke naloge, socialne naloge in strokovne naloge.

$\mathrm{Na}$ uspešnost vodenja ne vplivajo samo spretnosti in znanja vodii, ampak tudi lastnosti vodij, itd. Po pregledu literature ugotovimo, da vsak avtor s svojega vidika opredeliuje lastnosti, ki so značilne za uspešnega vodjo. $V$ tabeli 1 so prikazani pogledi nekaterih avtorjev na lastnosti, ki bi jih morali imeti uspešni vodje.

\section{Tabela 1: Predstavitev ključnih lastnosti uspešnih vodij}

\begin{tabular}{|l|l|l|l|}
\hline Northouse (2007) & $\begin{array}{l}\text { Kirkpatrick in Locke } \\
\text { (1991) }\end{array}$ & $\begin{array}{l}\text { Stogdill } \\
\text { (1974) }\end{array}$ & $\begin{array}{l}\text { Mayer } \\
(2004)\end{array}$ \\
\hline - inteligentnost & - prodornost & - uspešnost & - inteligentnost \\
- samozaupanje & - motiviranost & - vztrajnost & - osebnost v \\
- odločnost & - poštenost & - opazovanje & oźmenu \\
- poštenost & - zaupnost & - samozaupanje & - ustvarjalnost \\
- družabnost & - kognitivnost & - odgovornost & - izraznost \\
& - strokovnost & - kooperativnost & - empatija \\
& & - tolerantnost & - pozitivna \\
& & - vamopodoba \\
& & - družabnost & - odločnost \\
& & & - etična načela \\
& & & altruizem in \\
& & & filantropija \\
\hline
\end{tabular}

Vir: Northouse (2007, str. 18-19), Mayer (2004, str. 53-56)

Maxwell (2007, str. 10) predstavlja 21 pomembnih lastnosti, ki jih morajo imeti uspešni vodje, in sicer: značaj, karizma oz. očarljivost, predanost, komunikacijska sposobnost, pogum, razsodnost, moč osredotočenosti, velikodušnost, dajanje pobud, poslušanje, navdušenje, pozitiven pristop, reševanje težav, odnosi, odgovornost, prepričanost vase, samodisciplina, uslužnost, učliivost, vizija. Po primerjavah lastnosti lahko ugotovimo, da vsi avtorii poudarjajo lastnost "zaupanje vodje $v$ samega sebe" oziroma "spoštovanje samega sebe", svojih sposobnosti. Po mnenju 
Maxwella (2007, str. 101) je vodja lahko tisti, ki osvoji "zakone vodenja", vendar pa postane vodja učinkovit šele zaradi svoje notranjosti. Torej je pomemben vodja kot osebnost, ki ima jasno zavedanje o sebi, o tem kaj želi doseči in verjame $v$ samega sebe. Pomembno je tudi to, da ima vodja izoblikovano predstavo o sebi.

\section{Samopodoba}

Pogled vodje na samega sebe oziroma njegova samopodoba je $v$ odnosu do vodenih pomembna predvsem zaradi tega, ker vpliva na njegovo vedenje in $\mathrm{s}$ tem posledično tudi na vedenje vodenih ter tudi na samozavest in samozaupanje vodje $v$ okviru njegovih posameznih dimenzij samopodobe. Nastran Ule (1994, str. 238) pojasniuje, da so strokovnjaki ${ }^{7}$ na podlagi raziskav ugotovili, da je za dobre vodje značilna izgrajena in realna samopodoba o sebi.

Samopodobo si posameznik ustvarja kot edinstvena osebnost, ki po mnenju Allporta (Samuel, 1981, str. 3) predstavlja dinamično organizacijo posameznih psihodinamičnih sistemov, ki določajo posameznikovo značilno vedenje in misli. In ker smo ljudje socialna bitja, sai vzpostavljamo odnose $\mathrm{z}$ drugimi ljudmi, vpliva na kakovost vzpostavitve ter ohranitev odnosa z drugimi tudi osebnost vsakega posameznika in s tem povezana njegova podoba o samem sebi. To potriuje tudi Musek (2005, str. 1), saj meni, da »šele na podlagi ustreznega poznavanja osebnosti se lahko dobro znajdemo $v$ medsebojnih odnosih in si jih urejamo tako, kot si želimo«.

Tudi v procesu vodenja prihaja do interakcije med vodjo in vodenimi, torej do odnosa med različnimi osebnostmi. In zato sta osebnost posameznika in njegova podoba o sebi pomembni $v$ procesu vodenja. Stare in Seljak (2006, str. 189) pojasnjujeta, da »ugotavljanje potenciala za vodenje temelji prav na spoznanju osebnosti oziroma posameznih vidikov osebnosti«. Rogers (v: Kohont, 2005, str. 36) pa meni, da je vedenje posameznika kot edinstvene osebnosti odvisno od tega, kar si misli o sebi, kako se doživlja.

Pri opredelitvi poima samopodoba ugotovimo, da se $v$ slovenski literaturi uporablja številčnost izrazov, $\mathrm{ki}$ opredeljujejo pojem samopodobe (po Kobal, 2000, str. 17). Nekateri mu pravijo

7 Nastran Ule (1994, str. 238) navaja naslednje avtorje: Bird (1940), Mann (1959), Sorrentino in Boutillier (1975). 


\section{Samopodoba vodij v upravnih enotah}

samoidentiteta (Musek, 1993a, str. 359), identiteta (Zupančič, 1993, str. 208), socialni jaz (glej Nastran Ule, 1994, str. 292-302), samopercepcija (Ferbežer, 2008, str. 25). V angleški literaturi pa self (James, 1890, Cooley, 1902), self-actualisation (Rogers, 1951, Maslow, 1954), self-image (Offer et al, 1988), self-concept (Shavelson \& Bolus, 1982), self-esteem (Rosenberg, 1965), identity (Kroger, 1989) in drugo.

S konstruktom samopodobe se ukvarjajo številni ${ }^{8}$ strokovnjaki in ravno $v$ tem lahko poiščemo vzrok za številčnost ${ }^{9}$ pojmov, ki opredeliuje samopodobo. Vsem pojmom pa naj bi bilo po mnenju Nastran Uletove (1994, str. 296) skupno, da gre pri tem konstruktu za množico odnosov, ki jih posameznik vzpostavlja do samega sebe ${ }^{10}$. Posameznik $v$ ta razmeria vstopa postopoma, s pomočjo občutkov, predstav, vrednotenj in ocen samega sebe, svojih tipičnih socialnih naravnanosti, ki jih najprej preko prvotnega objekła, kasneje pa preko širšega družbenega okolja, razvija že od rojstva dalje. Gre za občutek lastne kontinuitete v prostoru in času ter dejstvo, da tudi drugi prepoznajo to kontinuiteto. S slovenskim pojmom "samopodoba" po mnenju Kobalove (2000, str. 24) razumemo vključenost dveh različnih konceptov, in sicer ameriškega self-concept in evropskega self-image. Self-concept opredeljuje zavestno, pojmovno, torej tudi logično in racionalno, self-image pa boli poudarja nezavedno, nagonsko in emocionalno. Oboje pa je združba psihosocialne, telesne in vedenjske razsežnosti osebnosti - samopodoba. Podobno self-concept opredeli tudi Tohme (v: Kobal, 1994, str. 31), sai pojasnjuje, da gre pri tem za celoto potez, podob, značilnosti, okusov, vrednot, pričakovani itd., ki jih posameznik bolj ali mani jasno zaznava pri samem sebi in jih $v$ skladu $z$ drugimi in $v$ skladu $s$ svojimi socialnimi vlogami ustrezno organizira in usklajuje.

Burns (1979) pojasnjuje, da je »samopodoba neka sestavljena podoba o tem, kaj mi mislimo o tem, kaj smo, kaj mislimo, da bi lahko bili, oziroma kaj bi lahko dosegli, in kaj mislimo, da drugi mislijo o nas, ter kaj bi radi bili, oziroma kakšni bi radi postali«. Burnett (1999, str. 2) in drugi opredeliujejo "samopodobo kot multidimenzionalna čustvena, ocenjevalna, primerjalna in kognitivna prepričanja, ki jih imajo ljudje o

8 Shavelson, Marsh, Offer, Rogers, Markus, Wurf, Fleming, Watkins, Kobal - Grum, Avsec itd.

9 To potriujeta tudi Ahmed in Bruinsma (2006, str. 554).

10 Podobno opredeliujeta koncept tudi Akram in Akram Naseem (2010, str. 78).

12 Uprava, letnik VIII, 4/2010 
posebnih lastnostih - in glavna tri področja teh lastnosti so: telesno, socialno in akademsko področje«. Zimbardo in Gerrig (1996, str. 528) pa pojasnjujeta, da je samopodoba dinamična struktura, saj vsebuje mnogo komponent, kot so:

- lastni spomini o samem sebi;

- prepričanja oziroma zaupanja o svojih lastnostih, motivih, vrednotah in sposobnostih;

- idealni "jaz" oziroma idealna samopodoba, ki bi jo zelo radi dosegli, pridobili in s tem možni "jazi" oziroma samopodoba, ki bi jo radi uvedli;

- pozitivno in negativno vrednotenje samega sebe;

- in prepričanja o tem, kaj drugi mislijo o nas.

Samopodoba je $v$ dobršni meri proizvod procesa socialnega konstruiranja in socialnega zrcaljenja - izjave drugih o nas so kot zrcalo, $v$ katerem vidimo samega sebe. Iz tega razloga tudi Adlešič (1999, str. 5) pojasnjuje, da »na razvoj samopodobe vplivajo različni socialnopsihološki procesi, kot so sprejemanje informacii od pomembnih drugih, socialno primerjanje z drugimi osebami, prevzemanje vlog, vrednot in stališč socialnega okolja, $v$ katerem posameznik živi, in identifikacija z modelom«. Tudi Nastran Ule (2004, str. 296) meni, da »nam samopodobo potrdijo le drugi ljudje, to so tisti, ki so za nas kakorkoli pomembni ali zanimivi. Toda to morajo storiti brez pritiska ali manipulacij. Pozitivne samopodobe, ki jih dosežemo s podkupovanjem drugih, niso kaj dosti vredne, saj jih lahko hitro ogrozi kak bolj avtonomen in kritičen opazovalec«. Pomen okolja oziroma drugih ljudi za razvoi samopodobe opredeliuje tudi Musek (1993b, str. 348-349), saj meni, da se $v$ našo samopodobo vtisnejo izjave drugih, recimo o tem, kako smo "pridni", "poredni", "živi", itd. Vsa ta sporočila se boli ali mani "primejo" naše duševnosti in postanejo del predstave, ki jo gojimo o sebi.

Po pregledu literature ugotovimo, da avtorii ${ }^{11} v$ svojih delih kot ključno za razvoj samopodobe poudarjajo predvsem obdobje otroštva in mladostništva. Adlešič (1999, str. 2) pa meni, da je razvoj samopodobe kontinuiran in značilen za vsako razvojno obdobje. To tudi pomeni, da kljub temu, da sta ključni obdobji za razvoi samopodobe otroštvo in mladostništvo, je obdobje odraslosti tisto obdobje, ko se vzpostavlja še

11 Kobal, Juriševič, Lewis, Adams, Hurlock, itd. 


\section{Samopodoba vodij $v$ upravnih enotah}

več novih področij samopodobe, ki so tesno povezane $\mathrm{z}$ razvojem osebnosti v obdobju odraslosti. Kobal (2000, str. 89) pojasnjuje, da se samopodoba s starostjo posameznika razvija in kot kažejo raziskave se tudi spreminja in strukturira. Ne razvija se kot celota, temveč se s starostjo vzpostavljajo zelo različna področja, od telesne, socialne, akademske in emocionalne samopodobe, itd. To potriuje tudi Shavelson (v: Adlešič, 1999, str. 4), ko pojasnjuje, da se samopodoba oblikuje postopoma $v$ človekovem razvoju - predvsem na prehodu iz otroštva v odraslost; $s$ starostjo pa postaja vse pogostejša s plastmi. Od življenjskega sloga odraslega posameznika, njegovih obveznosti, interesov, socialnih vlog in vpetosti $v$ medosebne odnose pa je odvisno, $v$ kolikšni meri bo posameznik svojo samopodobo še določneje strukturiral oziroma razmejil na posameznih področjih (glej Kobal Grum, 2004, str. 99).

\subsection{Samopodoba in samospoštovanje}

Samospoštovanje je pomemben korelat samopodobe oziroma njen vrednotni vidik (po Potočnik, 2003, str. 6). Kobal Grum (2003, str. 20) pa celo meni, da je samospoštovanje najpomembnejši korelat samopodobe. Če samopodoba zajema predvsem nevtralne samoopise, potem se samospoštovanje nanaša na vrednostne samoopise, $v$ katere so vpeti izrazito čustveni odnosi do samega sebe. Samospoštovanje je torej vrednostni odnos do samega sebe in zajema predvsem čustva, ki jih posameznik goji do sebe. Obstaja tudi pozitivna korelacija med samopodobo in samospoštovanjem - človek, ki ima visoko samopodobo (zlasti splošno) ima tudi visoko samospoštovanje. In obratno: oseba, ki o sebi nima visokega mnenja, se tudi ne ceni prav dosti (Kobal Grum, 2003, str. 21).

Samospoštovanje je kompleksen pojem, ki vključuje naravnanosti, prepričanja, dispozicije, želje, pričakovanja, čustva in dejanja, ki izražajo ali tvorijo občutek lastne vrednosti osebe. Vključuje tako prepoznavanje in razumevanje lastne vrednosti kot tudi željo in dispozicijo, da bi to vrednost zavarovala in ohranila (Marčič, 2006, str. 66). Rosenberg (v: Kobal, 2000 , str. 154) pojasnjuje samospoštovanje kot pozitivno ali negativno stališče do samega sebe. Pozitivno stališče ali visoko samospoštovanje pomeni, da se posameznik sprejema takšen, kakršen je, se ceni, je zadovoljen s sabo, se čuti vrednega spoštovanja. Oseba z nizkim samospoštovanjem oziroma negativnim stališčem do sebe, se ne ceni, se ne vidi kot vrednega, se mu lastne lastnosti ne zdijo vredne.

14 Uprava, letnik VIII, 4/2010 
Samospoštovanje pomeni odnos do samega sebe in zajema predvsem čustva, ki jih posameznik goji do sebe.

Rosenberg (1965) v eni izmed svojih raziskav tudi dokazuje, da se nizko samospoštovanje povezuje s simptomi, ki so značilni za tesnobo: tresenje rok, glavobol, povečan utrip srca, itd. (Rosenberg v: Avsec, 2010, str. 98). Znaki, ki so značilni za osebe, ki imajo slabo samopodobo oziroma nizko samospoštovanje, so ljubosumnost, slabo govorjenje o sebi, občutki krivde, nezmožnost dajanja komplimentov, neupoštevanje lastnih potreb, nezmožnost vprašati po tistem, kar bi radi, nezmožnost izražanja naklonjenosti drugim, kritičen odnos do drugih, primerjanje z drugimi, trajno poslabšanje zdravja (Račnik, 2008).

Kobal (2000, str. 165) pojasnjuje, da so številni raziskovalci ugotovili, da je zveza med samopodobo (samospoštovanjem) in anksioznostjo obratno sorazmerna - čim bolj ima posameznik izoblikovano pozitivno samopodobo in visoko samospoštovanje, tem nižja je njegova stopnja anksioznosti. In obratno: manj kot se oseba ceni in čuti vrednega, sposobnega in uspešnega, boli je tesnobna.

\subsection{Področni vidiki samopodobe}

Strukturni modeli samopodobe različnih avtorjev ${ }^{12}$ prikazujejo, da je samopodoba psihološki konstrukt, ki je sestavljen iz različnih področij oziroma podpodročij. Po pregledu literature ugotovimo, da avtorii ${ }^{13}$ samopodobo delijo na različna področja, in sicer splošna, socialna, telesna, emocionalna, religiozna, akademska, družinska samopodoba itd. S starostjo posameznika in z okoliščinami, $v$ katerih deluje posameznik, pa se področja, ki sestavljajo samopodobo, spreminjajo oziroma so lahko različna ${ }^{14}$ od posameznika do posameznika. Izkustveno ugotovimo, da je samopodoba vsakega posameznika in s tem tudi samopodoba vsakega vodje sestavljena predvsem iz splošne, akademske, socialne, telesne in emocionalne (čustvene) samopodobe. ${ }^{15}$

12 Shavelson, Bolus, Offer, Tam, Watkins itd.

13 Npr. James (1980), Fleming in Elovson (1988), Kobal (2000), Hattie (2003) itd.

14 Hattie $(2003$, str. 7) v svojem prispevku navaja kar 18 podpodročij samo za akademsko samopodobo in pojasnjuje, da jih je lahko še mnogo več.

15 Izpostavljenost posameznih področij, iz katerih je samopodoba sestavljena, je od posameznika do posameznika različna in tudi število področij je različno. 


\section{Samopodoba vodij $v$ upravnih enotah}

Emocionalna samopodoba predstavlja določena občutenja in prepričanja posameznika o izražanju, spoznavanju ter obvladovanju svojih čustev. Posameznik na primer razmišlja in vidi samega sebe kot ne/mirnega, ne/sproščenega in čustveno ne/uravnovešenega itd. Razmišlja tudi o tem, ali je pretežno dobro ali slabo razpoložen, ali je močno vznemirjen in kako potem obvladuje svoja čustva (glej Kobal, 2000, str. 205-220). Socialna samopodoba obsega zaznave ${ }^{16}$, prepričanja in presoje posameznika o odnosih z vrstniki in drugimi pomembnimi bližnjimi osebami, kot so starši, sorojenci, partner in sodelavci. Gre za zaznave posameznika o lastnih sposobnostih sklepanja prijatelistev, o lastni priljubljenosti in o kakovosti odnosov z bližnjimi. Del samopodobe pa se nanaša na vpliv posameznika na širšo skupnost oziroma na doživljanje odnosa do zakonov in družbenih moralnih norm (glej Kobal, 2000, str. 171-200). Musek (1993a, str. 345) pripisuje velik pomen socialni samopodobi in pojasnjuje, da so del naše samopodobe poimovanja in predstave, ki jih imamo o tem, kaj drugi mislijo o nas in o tem, kako naj samega sebe predstavimo in prikažemo pred drugimi, na socialnem prizorišču - socialni jaz. Hattie (2003, str. 18) pojasnjuje, da je socialna samopodoba za posameznika pomembna in veliko informacii o posamezniku izvira iz socialnih okoliščin. Vsak človek je namreč veliko $v$ prisotnosti drugih in njegovo osebnost drugi tudi predstavijo drugim - na podlagi tega pa človek gradi in spoznava sam sebe $v$ socialnih situacijah in si oblikuje določeno podobo o sebi.

Znak dobre socialne samopodobe vodii je, da zlahka sklepajo odnose $z$ vodenimi in jih tudi ohranjajo na kakovostni ravni. Vodje imajo jasno izoblikovano podobo o sebi in niso občutljivi na neodobravanje drugih, niso obsedeni s tem, kako najboli uspešno predstaviti sebe $v$ socialnem okolju. Vodje z visoko izraženo oziroma pozitivno socialno samopodobo nimajo težav z anksioznostjo oziroma predvsem socialno anksioznostjo, ki pomeni, da ljudje doživljajo nenehen (nepojasnjen) strah pred družabnimi situacijami, $v$ katerih bi jih lahko drugi ocenjevali ali obsojali. Takšen strah pa še naraste, če ugotovijo, da bi lahko pred omenjenimi ljudmi doživeli ponižanje. Vodje s socialno anksioznostjo so $\mathrm{v}$ odnosu z ljudmi neuspešni in pogosto občutijo tesnobo, napetost, vznemirjenost itd.

16 James (v: Hattie, 2003, str. 17) je socialni jaz opredelil kot "priznanja", ki smo jih dobili od svojih bližnjih (npr. družine, prijateljev). 
Po mnenju Schilderja (v: Fisher, 1990, str. 8) je »telesna samopodoba slika lastnega telesa posameznika, ki jo izoblikuje $v$ svojih mislih«. Thompson (v: Kuhar, 2004, str. 84) in drugi pa pojasniujejo, da »je telesna samopodoba terminološka oznaka za notranjo predstavo o lastnem zunanjem videzu. Ta notranji pogled oziroma mentalna slika pa je povezana $z$ občutii in mislimi, ki $v$ določenih situacijah vplivajo na vedenje. $\vee$ nekaterih primerih so lahko občutja, ki izhajajo iz ocene videza, pozitivna, $v$ drugih primerih pa so lahko tako negativna, da vodijo celo v depresijou. "Pozitivna telesna samopodoba lahko zviša samospoštovanje in prispeva $k$ uspešnim medosebnim ali poslovnim stikom, medtem ko lahko negativni pogled na lastno telo do take mere oslabi samozavest, da oseba ni pripravljena zapustiti varnega zavetja svojega doma« (Kuhar, 2004, str. 84-85). Grogonova (v: Kuhar, 2004, str. 86) meni, da gre pri telesni samopodobi za »človekove percepcije, mišljenje ali občutenja o njegovem ali njenem telesu. Percepcije se nanašajo na oceno velikosti telesa, mišljenje na vrednotenje telesne privlačnosti, občutja pa na čustva, povezana z obliko in velikostjo telesa«.

$\mathrm{Na}$ razvoj telesne samopodobe pomembno vplivajo medosebne izkušnje, npr. druženja, vrednotenje, tudi navidezno milo komentiranje videza. Osebe, ki so $v$ otroštvu in mladosti deležne pogostih kritik in draženja zaradi videza, razvijejo boli negativno telesno samopodobo, kajti telesna samopodoba se ne pozablja. Na negativno samopodobo vplivajo tudi specifični dogodki in situacije, ki sprožajo določena občutja in razmišljanje o videzu (Kuhar, 2004, str. 87). Kobal (2000, str. 65) pa pojasnjuje, da če je oblikovanje telesne samopodobe pri mladostniku moteno, se tudi splošna samopodoba in samospoštovanje ne moreta ustrezno razviti.

\section{Raziskava o samopodobi vodij $v$ upravnih enot}

Namen raziskave, ki je predstavljena $\vee$ prispevku, je bil poudariti pomen samopodobe vodij. Vodja namreč s svojim vedenjem vpliva na delovanje (vedenje) zaposlenih in $s$ tem posledično na uspešnost in učinkovitost upravne enote. Glavni cilj raziskovanja oziroma proučevanja je bil ugotoviti, kakšna je samopodoba vodij v upravnih enotah in katero področje samopodobe vodii je najnižje oziroma najvišje izraženo. Ciljna skupina, ki je torej sodelovala $v$ raziskavi, so bili vodje, ki $v$ organih državne uprave opravljajo razmeroma identične naloge in le-te opravljajo na območju celotne države. Takšnemu pogoju so ustrezali vodje 


\section{Samopodoba vodij $v$ upravnih enotah}

$\checkmark$ upravnih enotah in zato so bili $v$ raziskovalni vzorec vključeni vodje iz upravnih enot $v$ Sloveniii.

Raziskava je bila izvedena $\vee 57$ upravnih enotah (za nesodelovanje $\vee$ raziskavi so se odločili samo $v$ eni upravni enoti) in $v$ njej je sodelovalo 136 vodij, med katerimi je bilo mani kot $5 \%$ tistih, ki so strokovno tehnično osebje (javni uslužbenci) in so vodje organizacijskih enot. Največ, in sicer dobrih $66 \%$ je bilo takih, ki so uradniki oziroma vodje organizacijskih enot z do 30 zaposlenimi. $V$ raziskavi je sodelovala tudi polovica vseh načelnikov upravnih enot v Sloveniii oziroma dobrih $21 \%$ vseh anketiranih vodii. $V$ raziskavi je bilo ocenjevanih $8 \%$ vodij organizacijskih enot z več kot 30 zaposlenimi.

Vprašalnik ${ }^{17}$, ki je bil izoblikovan v sklopu raziskave, opredeljuje 45 vprašani in meri štiri vidike samopodobe, in sicer splošno, socialno, telesno in emocionalno samopodobo. Idejne zasnove za oblikovanje vprašani sta predstavljala Lestvica samospoštovanja ${ }^{18}$ avtorice Tanje Lamovec in tudi Vprašalnik SDQIII ${ }^{19}$ (vprašanja, s katerimi ugotavljamo splošno samopodobo). Visoko število točk oziroma visoka aritmetična sredina na vsaki posamezni dimenziji samopodobe kaže na to, da je samopodoba na tistem področja močno izražena.

\subsection{Rezultati raziskave}

Z raziskavo smo želeli ugotoviti, kako so izražena posamezna področja samopodobe pri vodjih, in sicer splošna, emocionalna, socialna in telesna samopodoba. Raziskava je pokazala, da sta področji socialne in telesne samopodobe $v$ primerjavi $s$ splošno in emocionalno samopodobo nižje izraženi. Preverjanje s T-testom je pokazalo, da statistično značilnih razlik ni zaznati samo med področjem socialne in telesne samopodobe. Med vsemi drugimi pari proučevanih področii samopodobe je mogoče zaznati statistično značilne razlike.

17 Poimenovan je kot Vprašalnik Lestvica samopodobe.

18 Lestvica samospoštovanja je krajše poimenovana kot LS.

19 Self Description Questionnaire III (Marsh, 1992) 
Samopodoba vodij v upravnih enotah

Grafikon 1: Področja samopodobe vodij v upravnih enotah (povprečna ocena)

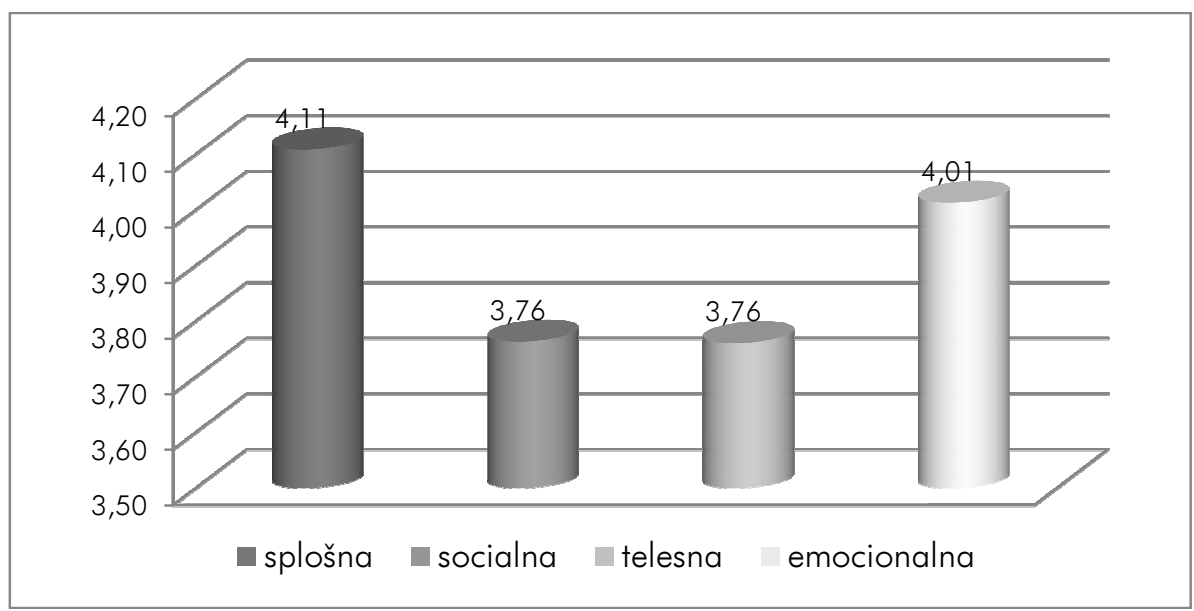

Vir: lastni

Rezultati raziskave (cf. grafikon 1) kažejo, da sta telesna in socialna samopodoba najnižje izraženi področji samopodobe, ki so bile merjene $v$ raziskavi, saj je povprečna ocena vodij za obe področji 3,76. Takšen rezultat kaže na zmerno izraženost socialne in telesne samopodobe proučevanih vodij $v$ upravnih enotah.

\section{Grafikon 2: Primerjava treh trditev v sklopu splošne samopodobe}

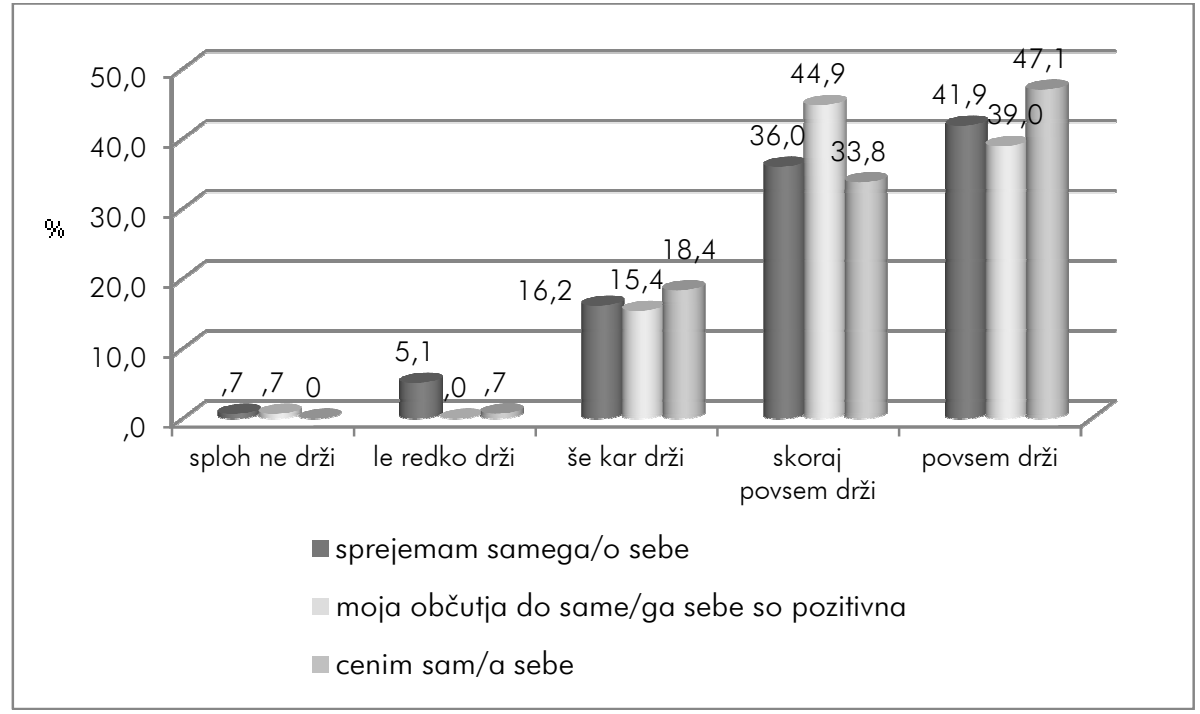

Vir: lastni

Med spremenljivkami (prikazane $\vee$ grafikonu 2) $\vee$ sklopu splošne samopodobe se statistično značilna razlika zazna med parom dveh 


\section{Samopodoba vodij v upravnih enotah}

spremenljivk, in sicer "sprejemam samega/o sebe" in "cenim sam/a sebe". Med drugimi pari spremenljivk ni zaznati statistično značilnih razlik. Rezultati pri paru kjer so statistično značilne razlike zaznane, kažejo, da slabih $67 \%$ proučevanih vodii, ki sprejemajo same sebe, hkrati tudi meni, da cenijo sebe. $11 \%$ vodij, ki sprejemajo samega sebe pa hkrati meni, da se še kar cenijo, ampak ne povsem. Dobrih $67 \%$ vodii pa hkrati meni, da sprejemajo same sebe in imajo tudi pozitivna občutenja do sebe.

$\checkmark$ sklopu spremenljivk emocionalne samopodobe sta najvišje ocenjeni spremenljivki "ne razmišljam o tem, da nisem nič vreden/na" $(4,38)$ in "nimam težav z depresivnostjo" $(4,32)$. Najnižje sta ocenjeni spremenljivki "mislim, da nisem pretirano občutljiv/a na neodobravanje drugih" s povprečno oceno 3,57 in "sem zadovoljen/a sam s sabo" s povprečno oceno 3,69. Preverjanje s T-testom kaže, da je med najvišje ocenjeno spremenljivko in najnižje ocenjeno spremenljivko mogoče zaznati statistično značilne razlike (cf. grafikon 3).

\section{Grafikon 3: Primerjava dveh spremenljivk v sklopu emocionalne samopodobe}

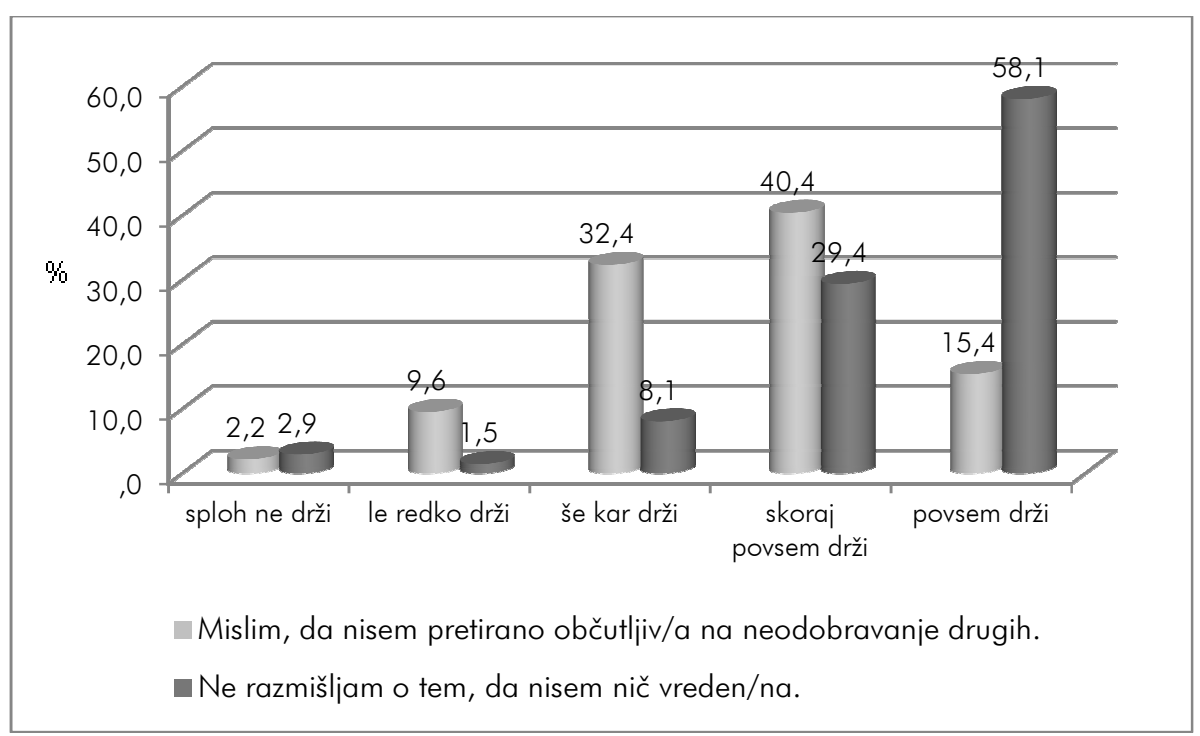

Vir: lastni

Rezultati, ki so prikazani v grafikonu 3, kažejo, da samo dobrih $55 \%$ proučevanih vodii meni, da niso občutljivi na neodobravanje drugih. Več kot $11 \%$ vodii pa je občutljivih na neodobravanje drugih. Določena občutljivost vodij na neodobravanje drugih je potrebna, saj na tak način vodje tudi začutijo in pokažejo svoja čustva. Toda bolj kot niihova občutliivost na neodobravanje drugih je pomembna empatija oziroma 
sposobnost "vživljanja" v vodene oziroma zaznavanja čustev in potreb vodenih. Določeno (ne)občutljivost vodij na (ne)odobravanje drugih se lahko razume tudi na način, da želijo vodje ugajati drugim in ker jih nekateri drugi ne odobravajo, se pri vodjih pojavljajo določena občutenja in nekateri so na takšna občutenja občutliivi bolj kot drugi. Analiza rezultatov tudi kaže, da dobrih $87 \%$ ocenjevanih vodij ne razmišlja o tem, da niso nič vredni. Dobrih $4 \%$ vodii pa razmišlja o tem, da niso nič vredni. $52 \%$ vodij hkrati meni, da ne razmišlia o tem, da niso nič vredni, in tudi misli, da niso pretirano občutljivi na neodobravanje drugih. Dobrih $9 \%$ tistih vodij, ki ne razmišlja o tem, da niso nič vredni, pa misli, da so pretirano občutljivi na neodobravanje drugih.

$\checkmark$ okviru emocionalne samopodobe so bile na podlagi T-testa zaznane statistično značilne razlike tudi med spremenljivkama, ki se nanašata na depresivnost in napetost ter zaskrbljenost (cf. grafikon 4).

\section{Grafikon 4: Primerjava dveh spremenljivk v sklopu emocionalne samopodobe}

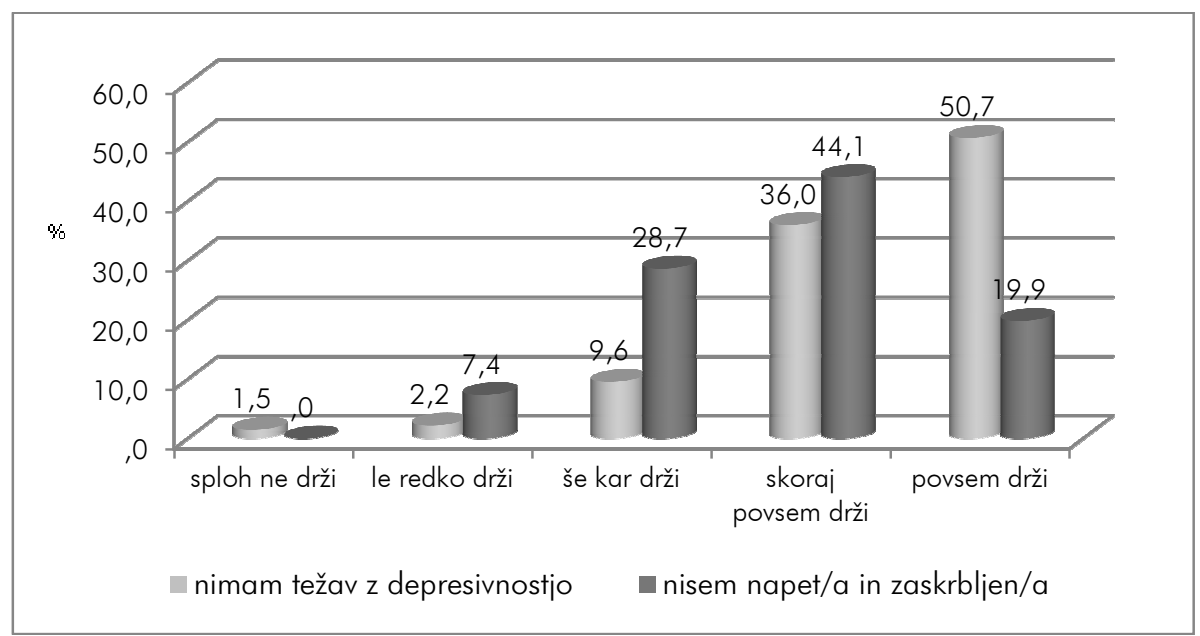

Vir: lastni

Rezultati, ki so prikazani v grafikonu 4, kažejo, da dobrih $86 \%$ vodii meni, da nima težav z depresivnostjo. Pričakovali bi, da bodo enaki odstotki tudi pri trditvi nisem napet in zaskrbljen, ki je vsebinsko tesno povezana z depresivnostjo - toda kot kažejo rezultati, samo $64 \%$ vodij meni, da niso napeti in zaskrbljeni. Dobrih 61 \% vodii, ki meni, da niso napeti in zaskrbljeni, hkrati tudi meni, da nima težav z depresivnostjo. Slabih $3 \%$ ocenjenih vodij, ki hkrati meni, da nima težav z depresivnostjo, pa sebe ocenjuje kot napete in zaskrbljene. Dobra $2 \%$ ocenjevanih vodij 


\section{Samopodoba vodij $v$ upravnih enotah}

pa je takšnih, ki meni, da imajo težave z depresivnostjo in so hkrati napeti in zaskrbljeni.

Rezultati spremenljivk socialne samopodobe kažejo, da socialna samopodoba vodij ni visoko izražena oziroma je zmerno izražena, kar zbuja skrb. Preverjanje s T-testi kaže, da obstajajo med nekaterimi spremenliivkami statistično značilne razlike. Statistično značilna razlika obstaja med spremenljivkama "ne skrbi me, če se z drugimi ljudmi ne razumem prav dobro" in "ne skrbi me misel na to, ali me pri delu drugi ocenjujejo kot uspešnega/o ali neuspešnega/o" (cf. grafikon 5).

\section{Grafikon 5: Primerjava dveh spremenliivk socialne samopodobe}

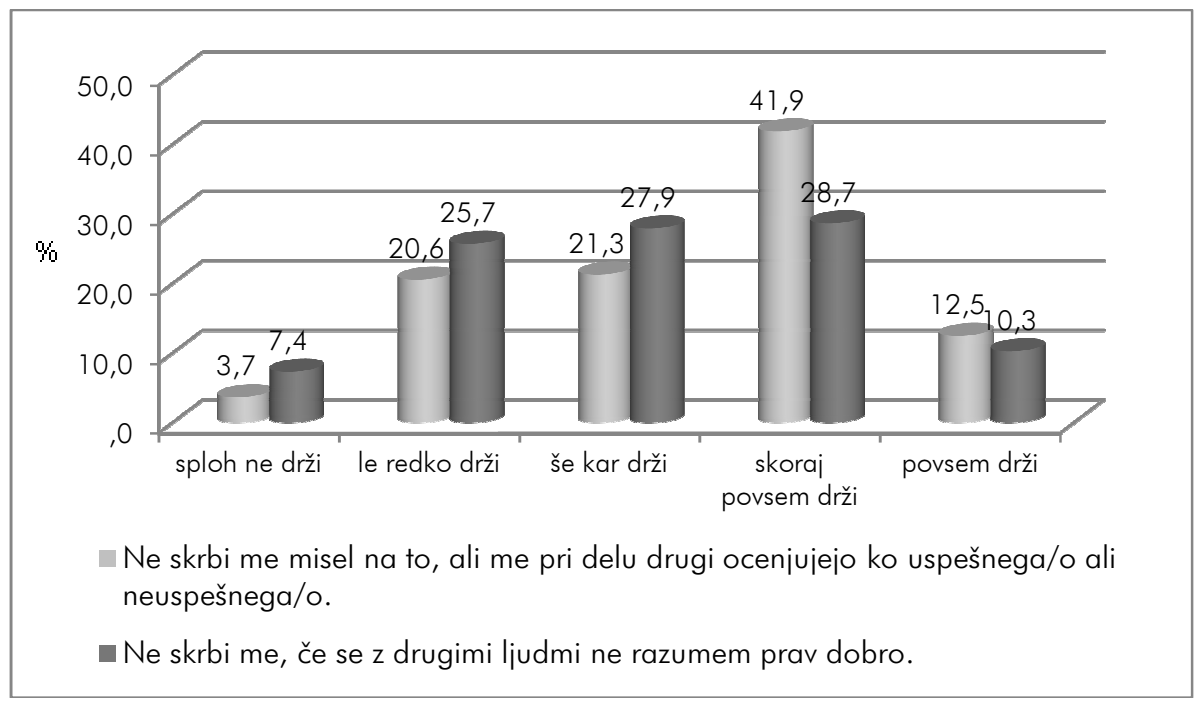

Vir: lastni

Rezultati v grafikonu 5 kažejo, da dobrih $54 \%$ ocenjevanih vodij meni, da jih ne skrbi misel na to, ali jih pri delu drugi ocenjujejo kot uspešnega/o ali neuspešnega/o. Slabih $24 \%$ vodii pa skrbi, če jih drugi pri delu ocenjujejo kot uspešne oziroma neuspešne. Analiza rezultatov tudi kaže, da samo 36 \% vodij, ki meni, da jih ne skrbi misel na to, ali jih drugi pri delu ocenjujejo kot uspešnega ali neuspešnega, hkrati tudi meni, da jih ne skrbi, če se z drugimi ne razumejo prav dobro. $21 \%$ ocenjevanih vodii pa hkrati meni, da jih skrbi misel na to, ali jih drugi pri delu ocenjujejo kot (ne)uspešne, in da jih tudi skrbi, če se z drugimi ljudmi ne razumejo prav dobro. 
Grafikon 6: Primerjava dveh spremenliivk socialne samopodobe

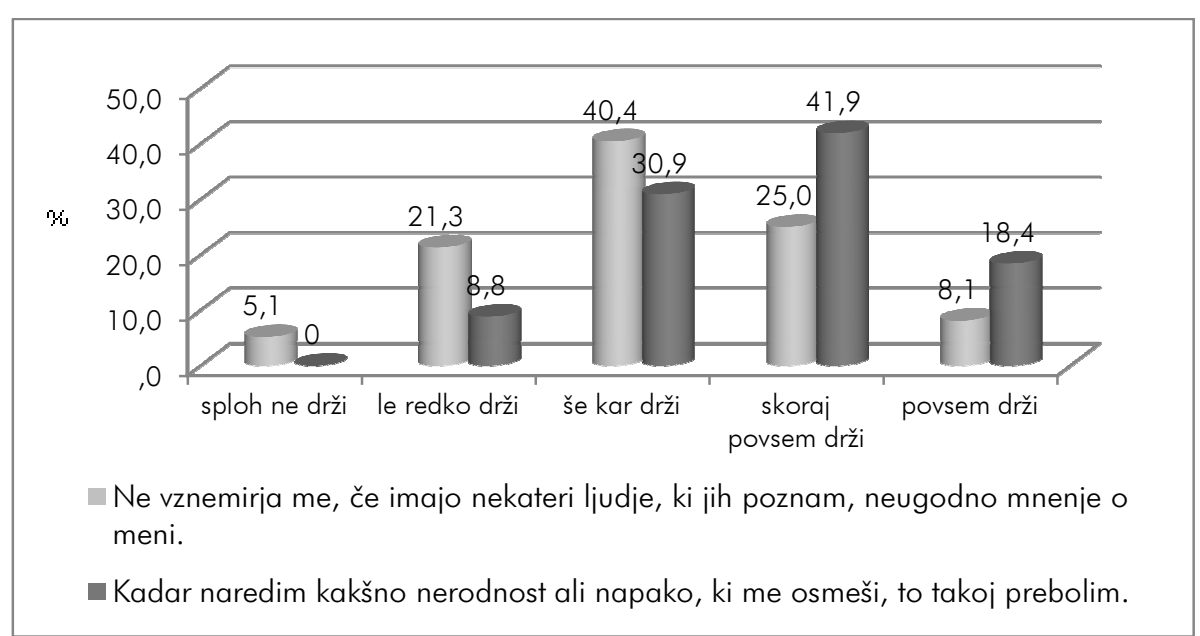

Vir: lastni

Rezultati, ki so prikazani v grafikonu 6, kažejo, da $60 \%$ proučevanih vodij meni, da če naredijo kakšno nerodnost ali napako, ki jih osmeši, to takoi prebolijo. Slabih $9 \%$ vodii pa meni, da napake ali nerodnosti, ki jih osmeši, ne prebolijo takoj. Analiza rezultatov je tudi pokazala, da $25 \%$ proučevanih vodii, ki takoj prebolijo napako ali nerodnost, ki jih osmeši, hkrati tudi meni, da jih ne vznemirja, če imajo nekateri ljudje, ki jih poznajo, neugodno mnenje o njih. Slabih $6 \%$ vodij pa hkrati meni, da jih vznemirja, če imajo ljudje o njih neugodno mnenje in tudi ne morejo takoj preboleti napake, $\mathrm{ki}$ jih osmeši. Preverjanje $\mathrm{s}$ T-testom med spremenljivkama, ki sta prikazani grafikonu 6, je pokazalo, da so med spremenljivkama zaznane statistično značilne razlike.

Tudi področje telesne samopodobe je za vodje pomembno, saj se nanaša na notranje predstave vodii $\circ$ njihovem $\circ$ zunanjem videzu. Rezultati posameznih spremenljivk za področje telesne samopodobe kažejo, da je samopodoba vodij v upravnih enotah zmerno izražena in da je med spremenljivkami $v$ okviru telesne samopodobe zaznati nekaj statistično značilnih razlik. $V$ sklopu spremenliivk telesne samopodobe preverba s T-testom kaže, da so bile zaznane statistično značilne razlike med nekaterimi pari spremenljivk, ki so prikazani v grafikonu 7 .

Rezultati, ki so prikazani v grafikonu 7 , kažejo, da $74 \%$ ocenjevanih vodij meni, da so boli privlačni kot večina ljudi. Dobrih $44 \%$ vodii pa meni, da imajo občutek, da sploh niso telesno boli privlačni od večine prijateljev in kolegov. Takšni rezultati so zanimivi in to še posebej, ker so 


\section{Samopodoba vodij v upravnih enotah}

prijatelji in kolegi tisti, ki najbolj vplivajo na posameznika, oziroma po katerih se posameznik zgleduje in najboli občuteno doživlja njihove komentarje. In če so prijatelii in kolegi v veliki večini bolj telesno privlačni od vodii, vpliva to na niihove občutke oziroma zaznavanja telesnega videza ter posledično vpliva na slabši pogled na svoje telo (je razvidno $v$ zmerno izraženi telesni samopodobi). Slabih $3 \%$ vodii pa sanjari ${ }^{20}$, da bi bili boli privlačni.

\section{Grafikon 7: Primerjava treh spremenliivk telesne samopodobe}

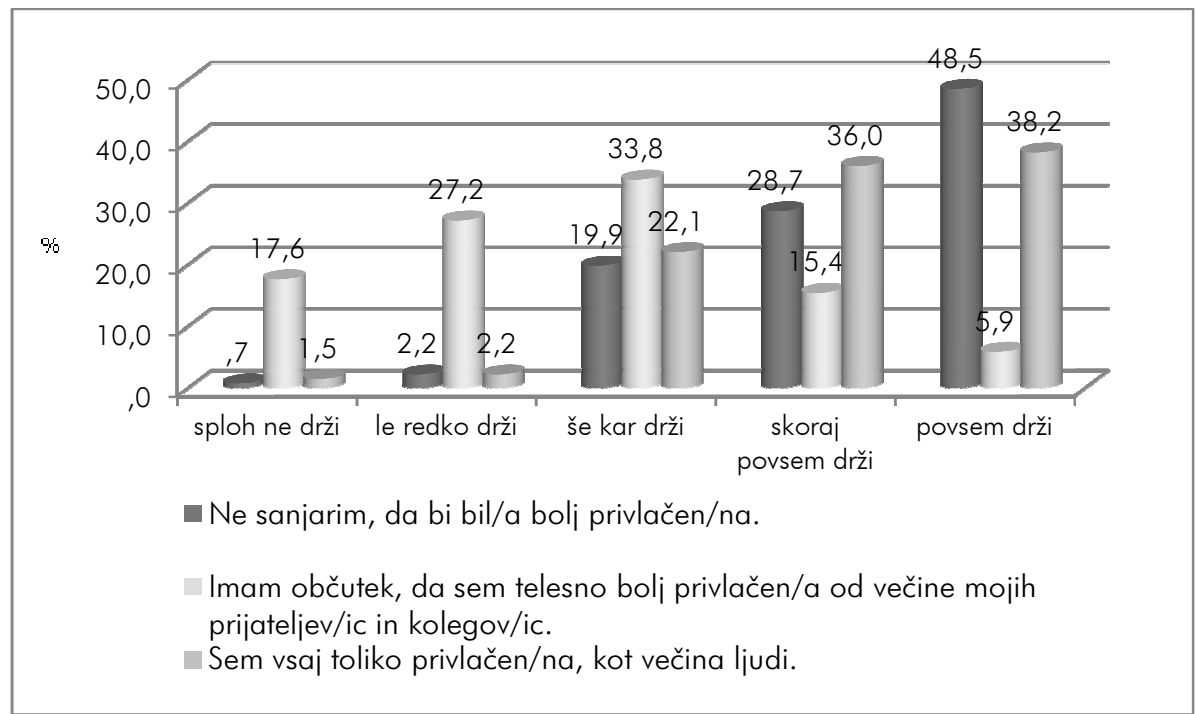

Vir: lastni

Rezultati, ki so prikazani v grafikonu 8, pa kažejo, da $64 \%$ proučevanih vodij trdi, da so zadovoljni s svojim telesnim videzom. 8,1 \% vodij $\vee$ upravnih enotah pa nima najboljšega pogleda na svoj telesni videz - to posledično pomeni, da lahko takšen pogled slabo vpliva na niihovo vedenje do vodenih oziroma na medosebne odnose.

Rezultati, ki so prikazani $v$ grafikonu 8, tudi kažejo, da dobrih $77 \%$ proučevanih vodij meni, da ne sanjarijo o tem, da bi bili boli privlačni. Precej mani vodij $v$ primerjavi z tistimi, ki ne sanjarijo, da bi bili boli privlačni, pa skrbi kaj si drugi mislijo o njih. Samo dobrih $44 \%$ proučevanih vodij meni, da jih ne skrbi kaj drugi mislijo o njih. Takšen rezultat je smiselno primerjati tudi s podobnimi rezultati spremenljivk, ki so

20 Samo $2 \%$ vodij hkrati meni, da sanjarijo, da bi bili boli privlačni in imajo kar precej močan občutek, da niso telesno boli privlačni od svojih prijateljev/ic in kolegov/ic. 
prikazane $v$ sklopu socialne samopodobe. $V$ primeriavi se ugotovi, da odstotek ne preseneča, saj tudi dobrih $38 \%$ vodij ne vznemirja, če imajo nekateri ljudje, ki jih poznajo, neugodno mnenje o njih in $39 \%$ vodij tudi meni, da jih ne skrbi, če se z drugimi ljudmi ne razumejo prav dobro.

Grafikon 8: Primerjava treh trditev telesne samopodobe

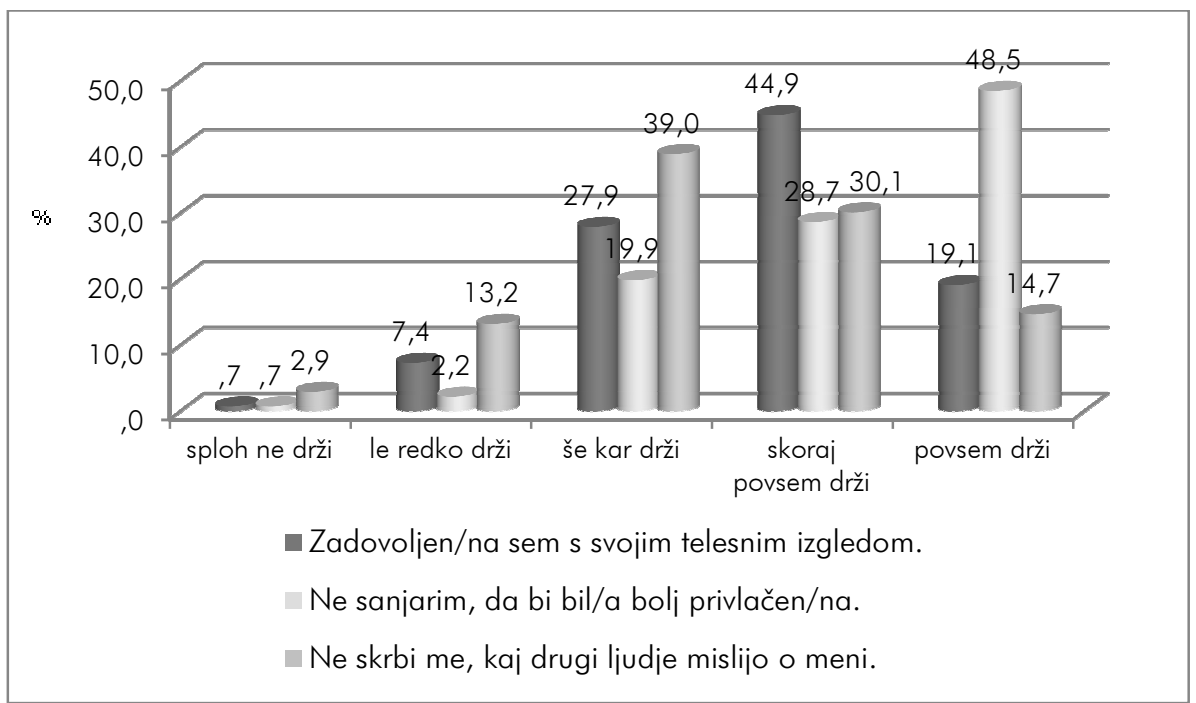

Vir: lastni

\subsection{Razprava}

Rezultati opravliene raziskave o samopodobi vodij na upravnih enotah kažejo, da sta najnižje izraženi področji socialne in telesne samopodobe. Za vodje je pomembno, da imajo visoko izraženo samopodobo na socialnem področju, saj je to področje samopodobe povezano s tem, kakšno predstavo oziroma prepričanja ima posameznik o sebi na področju odnosov z ljudmi (npr. vodenimi). Gre za predstave oziroma zaznave vodii $\bigcirc$ nihovi priljubljenosti in nihovih lastnih sposobnostih sklepanja dobrih odnosov $z$ vodenimi, njihovega motiviranja, sposobnosti prepričevanja vodenih in vključevanja $v$ socialno okolje. Če je samopodoba na t.i. socialnem področju nizko izražena oziroma slaba - pomeni to, da imajo vodje slab pogled na sebe na področju odnosov oziroma začnejo dvomiti $v$ same sebe $v$ razmerju do drugih. Ker niso tako priljubljeni $v$ družbi, kot si želijo biti oziroma ker mogoče vodeni bolj zaznavajo druge kot pa nih, jih to $v$ odnosu do vodenih ovira in pri niih se pojavlja občutek negotovosti, ali bodo res zmogli vzpostaviti primeren odnos z vodenimi, tako da jih bodo vodeni 


\section{Samopodoba vodij $v$ upravnih enotah}

sprejeli in jim zaupali. Gre tudi za predstave vodij o tem, kakšno mnenje imajo vodeni o njih in kako naj sebe prikažejo na socialnem prizorišču.

Rezultati raziskave za področje socialne samopodobe za proučevane vodje kažejo, da je socialna samopodoba zmerno izražena. Nekatere spremenljivke kažejo skrb zbujajoče rezultate in to $v$ povezavi s tem, da se od vodii pričakuje, da so sposobni sklepati dobre odnose $z$ vodenimi in jih vodeni spoštujejo oziroma $v$ njih vidijo vzornike, ki so jim zgled s svojimi sposobnostmi in načelnostio. Na podlagi rezultata se lahko sklepa, da je vedenje vodii do vodenih omejeno in vpliva na odnos do vodenih, ker če vodje dvomijo $v$ svoje sposobnosti vzpostavljanja odnosa z vodenimi bodo imeli vodje manj uspešnega odnosa $z$ vodenimi (prisoten je lahko tudi strah ali bom uspešen) in pri vodenih se bo pojavil občutek dvoma $v$ avtoriteto oziroma sposobnost, resnost vodij. Rezultati socialne samopodobe tudi nakazujejo, da se pri veliki večini vodij ne pojavlja t.i. generalizirana anksioznost, ki pomeni motnjo $s$ tesnobnostjo, zaskrbljenostjo in napetostjo, povezano s strahom pred nesrečami ali z neustrezno zaskrbljenostjo zaradi zdravja, družine ali službe. Pri tistih nekaj odstotkih $(7,4 \%)$ vodij, ki pa menijo, da so napeti in zaskrbljeni, in tistih, ki menijo, da imajo težave z depresivnostjo (3,7 \%), pa se lahko sklepa, da se ubadajo z generalizirano anksioznostjo. Na podlagi vseh rezultatov $v$ sklopu socialne samopodobe se predvideva, da velika večina vodii ne trpi zaradi socialne anksioznosti, oziroma ne doživljajo nenehnega in neracionalnega strahu pred družabnimi (socialnimi) situacijami, $\vee$ katerih bi jih drugi ljudje lahko ocenjevali ali obsojali, oziroma se ne boiijo lastnega neuspeha zaradi kakšne lastne napake.

Podobno kot socialna samopodoba je tudi telesna samopodoba najnižje izražena med samopodobami, ki so bile merjene $v$ raziskavi. Telesna samopodoba je za vodje pomembna in to predvsem $v$ smislu, da si ustvarijo pozitiven pogled na svoj zunanji (telesni) videz in da množične sugestije medijev o idealnem telesu ne zaznavajo na negativen način oziroma na način, ki bi imel za posledico slabo lastno samopodobo, saj lahko le ta slabo vpliva na njihovo vedenje in odnos z vodenimi. $\mathrm{Na}$ uspešno vzpostavljanje odnosa z vodenimi oziroma z drugimi ljudmi lahko pomembno vpliva predvsem pozitivna telesna samopodoba, saj lahko zviša samospoštovanje in prispeva $k$ uspešnosti odnosov. Negativen pogled na lastno telo lahko zniža samozavest in to tako, da si posameznik ne upa $v$ družbo ljudi. Torej je za vodje še posebej zaželena pozitivna telesna samopodoba, saj vpliva na samospoštovanje in prispeva $\mathrm{k}$ dobrim 
medosebnim odnosom. Rezultati opravljene raziskave kažejo, da so točkovne ocene nekaterih spremenljivk telesne samopodobe nizke. Tako na primer $44 \%$ vodij meni, da imajo občutek, da telesno niso boli privlačni od svojih prijateljev in kolegov. To lahko pomeni, da $v$ kolikor so vodje veliko $v$ družbi svojih prijateljev in kolegov, ki so telesno bolj privlačni od njih, se lahko pojavijo določene posledice pri vodjih. To pa predvsem $v$ obliki nekega ljubosumja vodij in $\mathrm{v}$ obliki občutka manjvrednosti oziroma neprivlačnosti. Kljub temu, da so vodje privlačni, ampak ker je moč vpliva prijateljev in kolegov $v$ primerjavi $z$ drugimi ljudmi tako močna, je mogoče, da se pojavijo negativni pogledi na svoj zunanji (telesni) videz. Vsi ti občutki, ki se lahko pojavijo pri vodjih, so predvsem povezani z željo, da ne bi slabo izstopali iz kroga svojih prijateljev in kolegov. Zato mogoče tudi sanjarijo, da bi bili boli privlačni.

\section{Zaključek}

Pomemben vidik vodje, ki vpliva na njegovo vedenje in posledično na vedenje vodenih, je tudi vidik osebnosti vodje oziroma iz tega izhajajoč vidik dojemanje, sprejemanja vodje samega sebe. Pozitiven odnos vodje do sebe pomeni, da je zadovoljen s sabo in svojim življenjem. Torej, da vodja lahko razume druge, mora najprej razumeti sebe. Vsak vodja si izoblikuje tudi določeno predstavo o sebi, o tem kakšen je in kakšen bi želel biti. V strokovni literaturi se je za takšno opredeljevanje izoblikoval pojem samopodoba. Pri samopodobi gre torej za določene odnose oziroma predstave, ki jih oblikuje posameznik do samega sebe in to na ravni zavestnega in nezavednega, pri čemer nezavedno prekriva plašč obrambnih mehanizmov, ki omogočajo "jazu" (zavestnemu vidiku), da nadzoruje "ono" (nezavednemu) in s tem preprečuje vdor nezaželenih nagonskih impulzov. Toda pri samopodobi ne gre samo za običajne predstave posameznika o samem sebi, ampak gre za zelo zapletene notranje procese, ki so povezani z idealnim oziroma s tem, kako naj posameznik sebe predstavi na socialnem prizorišču pred pomembnimi drugimi ljudmi.

$\checkmark$ procesu vodenja je pomembna predvsem pozitivna samopodoba vodje. Vodja s pozitivno ali negativno samopodobo vpliva na vedenje vodenih in $s$ tem posledično na zadovoljstvo vodenih in uspešnost vodenja. Tisti vodja, ki nima pozitivnega mnenja oziroma pogleda na samega sebe, ima določene lastnosti, ki jih vodeni občutijo, in če vodja z negativno oziroma nizko samopodobo ne zaupa vase, sebe ne spoštuje, 
Jernej Buzeti, Janez Stare

\section{Samopodoba vodij v upravnih enotah}

se ne ceni, je zaprt vase, se boji stikov z ljudmi, se boji soočenja z ljudmi - ne more učinkovito vplivati na vodene, saj vodeni to občutijo. Konstrukt samopodobe je predmet številnih raziskav med različnimi skupinami ljudmi. Povezanosti vsebin samopodobe $z$ vsebinami vodenja so pomembne $v$ odnosu do ljudi oziroma še posebej pri ključnem dejavniku $\checkmark$ procesu vodenja, in sicer pri vodji.

Rezultati raziskave o samopodobi vodij v upravnih enotah kažejo izraženost splošne, emocionalne, socialne in telesne samopodobe in nakazujejo potrebo po nadaljnjem raziskovanju, saj so bila z raziskavo preverjana samo nekatera področja. Vsekakor bi bilo smiselno nadaljnja raziskovanja samopodobe vodij povezati z uspešnostjo vodenja oziroma s tem, kako izraženost samopodobe vpliva na uspešnost vodenja.

Mag. Jernej Buzeti je zaposlen kot raziskovalec na Fakulteti za upravo Univerze v Ljubljani, kjer je leta 2010 uspešno zaključil magistrski študij. Predmet raziskovanja, s katerim se ukvarja, je povezan s področjem ravnanja s človeškimi viri oziroma organizacijo javnega sektoria. Sodelvje tudi pri pripravi in izvedbi vaj.

Dr. Janez Stare je zaposlen kot docent za področje organizacije javnega sektorja na Fakulteti za upravo Univerze v Ljubljani. Leta 1999 je zaključil podiplomski magistrski študij na kadrovsko-izobraževalni smeri na Fakulteti za organizacijske vede Univerze v Mariboru. Leta 2005 je s temo Povezanost osebnostnega potenciala za vodenje z uspešnostjo vodenja $v$ organih državne uprave ubranil doktorsko disentacijo na Fakulteti za upravo Univerze v Ljubljani. Njegova raziskovalna področja so organizacija javnega sektorja, ravnanje s človeškimi viri in vodenje. Od leta 2008 je prodekan za študijske zadeve na Fakulteti za upravo Univerze v Liubliani. 


\section{Literatura in viri}

- Adlešič, I. (1999). Samopodoba osnovnošolskih otrok. Psihološka obzoria. Letnik 8, št. 2-3, str. 201-205.

- Ahmed, W. \& Bruinsma, M. (2006). A Structural Model of Self-concept, Autonomous Motivation and Academic Perfomance in Cross-cultural Perspective. Electronic Journal of Research in Educational Psychology. Letnik 4 , št. 10, str. 551-576.

- Akram, I. \& Akram Naseem, M. (2010). Self Concept and Social Adjustment among Physically Handicapped Persons. European Journal of Social Sciences. Letnik 15, št. 1, str. 7-85.

- Avsec, A. (2010). Samopodoba. V: Avsec, A. (Ur.): Psihodiagnostika osebnosti. Ljubliana: Filozofska fakulteta, Oddelek za psihologijo.

- Bass, B. M. (1990): Handbook of Leadership - theory, research, and managerial applications (third edition). New York: The Free Press.

- Brajša, P. (1983). Vodenje kot medosebni proces. Ljubliana: DDU Univerzum.

- Branden, N. (2000). Samozavestno vodenje. Ljubliana: Inštitut za razvijanje osebne kakovosti.

- Burnett, P. C., Craven, R. G. \& Marsh, H. W. (1999). Enhancing students' self-concepts and related constructs: A critical longitudinal analysis capitalising on and combining promising enhancement techniques for educational settings. Pridoblieno s:

http://eprints.qut.edu.au/27108/1/27108.pdf.

- Burns, R. B. (1979). The self concept: Theory, measurement, development and behavior. London: Longman.

- Ferbežer, I. (2008). Samopodoba mlajših nadarienih otrok. V: Ferbežer, Ivan, Težak, S., Korez, I. (Ur): Samopodoba mlajših nadarienih otrok. Ljubljana.

- Fisher, S. (1990). The evolution of psychological concepts about the body. V: Cash, Thomas F. (Ur.): Body images: development, deviance and change. New York: Goilford.

- Hattie, J. (2003). The status and direction of self-concept research: The importance of importance. Pridoblieno 30. 7. $2003 \mathrm{~s}$ :

http://www.education.auckland.ac.nz/webdav/site/education/shared/hattie/ docs/status-of-self-concept-research-waiheke-(2003).pdf. 


\section{Samopodoba vodij v upravnih enotah}

- Hellriegel, D. \& Slocum, J. W.(1996). Management. Cincinnati: SouthWestern.

- Hočevar, M., Jaklič, M. \& Zagoršek, H. (2003). Ustvarjanje uspešnega podjetja - akcijski pristop k strateškemu razmišljanju, vodenju in nadziranju. Zbirka Manager. Ljubljana: GV Založba, založniško podjetje, d.o.o.

- Katz, R. L. (1955). Skills of an effective administrator. Harvard business review. Letnik 33, št. 1, str. 33-42.

- Kobal, D. (2000). Temelini vidiki samopodobe. Ljubliana: Pedagoški inštitut.

- Kobal, D. (1994). Samopodoba - zavestna ali tudi nezavedna razsežnost osebnosti?. Psihološka obzoria - Horizons of psychology. Letnik 3, št. 3-4, str. 25-35.

- Kobal Grum, D. (2003). Bivanje samopodobe. Ljubljana: I2 družba za založništvo, izobraževanje in raziskovanje d.o.o.

- Kobal Grum, D. (2004). Pomen samopodobe bibliotekarja v komunikacijskem procesu. Pridobljeno 22. 9. 2004 s: http://revijaknjiznica.zbds-zveza.si/lzvodi/K0403/kobal.pdf.

- Kohont, K. (2005). Custvena inteligenca pri vodenju v neprofitnih organizacijah. Ljubljana: Fakulteta za socialno delo.

- Kuhar, M. (2004). V imenu lepote - družbena konstrukcija telesne samopodobe. Ljubliana: Fakulteta za družbene vede.

- Marčič, R. (2006). Razlike med spoloma v samopodobi, samospoštovanju in nekaterih zdravju škodljivih vedenjih. Anthropos. Letnik 38, št. 3-4, str. 63-76.

- Mayer, J. (2004). Etična načela vodenja. V: Kovač, J., Mayer, J. \& Jesenko, M. (Ur.): Stili in značilnosti uspešnega vodenja. Kranj: Moderna organizacija.

- Maxwell, J. C. (2007). 21 nepogrešljivih lastnosti vodje: postanite človek, ki mu bodo drugi hoteli slediti. Ljubljana: Lisac\&Lisac d.o.o.

- Musek, J. (1993a). Znanstvena podoba osebnosti. Ljubljana: Educy d.o.o.

- Musek, J. (1993b). Osebnost pod drobnogledom. Maribor: Obzorja.

- Musek, J. (2005). Psihološke dimenzije osebnosti. Ljubliana: Filozofska fakulteta, Oddelek za psihologijo.

- Nastran Ule, M. (1994). Temelii socialne psihologije. Zbirka Alfa. Ljubliana: Znanstveno in publicistično središče. 
- Northouse, P. G. (2007). Leadership: theroy and practice. London: Sage Publications.

- Račnik, M. (2008). Samopodoba in prepričanje. Pridoblieno 1. 12. $2008 \mathrm{~s}$ : http://www.vodja. net/index.php? blog $=1 \& p=187 \&$ more $=1 \& c=1 \& t b=1 \& p$ $b=1$.

- Samuel, W. (1981). Personality, searching for the sources of human behavior. New York: McGraw-Hill, Inc.

- Stare, J. (2005). Povezanost osebnostnega potenciala za vodenje z uspešnostjo vodenja v organih državne uprave. Doktorska disertacija. Ljubliana: Univerza v Ljubljani, Fakulteta za upravo.

- Stare, J. \& Seljak, J. (2006). Vodenje liudi v upravi: povezanost osebnostnega potenciala za vodenje z uspešnostjo vodenja. Ljubljana: Fakulteta za upravo.

- Yukl, G. A. (2002). Leadership in organizations. New York: Prentice - Hall International.

- Zimbardo, P. G. \& Gerrig, R. J. (1996). Psychology and Life, Fourteenth Edition. New York: HarperCollins Publishers Inc.

- Zupančič, M. (1993). Razvojne naloge mladostnika in institucionalno izobraževanje. Psihološka obzoria. Letnik 2, št. 3-4, str. 207-213. 